\title{
ON THE COMBINATION OF PROTEIN AND THIAMINE
}

\author{
CHOTEN INAGAK I, HIROYASU FUKUBA, TAKAKO MIYAKAWA \\ AND SHOHKO IWATA \\ Laboratory of Nutrition Chemistry, Ochanomizu University, Bunkyo-ku, \\ Otsuka, Tokyo
}

(Received October 30, 1959)

The adsorption of thiamine to acid clay or zeolite is practically applied for the determination of the vitamin. It was found that the waste liquor obtained by centrifugation of soy bean curd, previously thawed, pressed for hydration, and soaked for a short time in thiamine solution, contained little thiamine.

It was further investigated whether the disappearance of thiamine is due to the combination of the vitamin to protein or to its decomposition product by some factors contained in the curd. Having certified that this phenomenon was based upon the former mechanism, the following points were further investigated. (a) The characteristics of this reaction. (b) The determination of the thiamine adsorbed on protein. (c) The prosthetic group of protein concerned with this reaction.

\section{EXPERIMENTAL}

\section{Materials}

Frozen Soy Bean Curd - This material, manufactured at the factory and aged for a few days in a refrigerator, was transported to the laboratory and stored in a freezer $\left(-10^{\circ}\right)$. When necessary, this was thawed with tap water and pressed for hydration.

Glycinin - With 10 per cent $\mathrm{NaCl}$ solution, the globulin fraction was extracted from soy bean powder, which had been defatted with petroleum ether at low temperature, and the sediments formed in cellophane sack during the dialysis of this extract were collected and dehydrated with ethanol. This dehydrated powder was used as a glycinin sample.

Egg Albumin - Repurified egg albumin with $0.2 \mathrm{~N} \mathrm{H}_{2} \mathrm{SO}_{4}$ and $\mathrm{Na}_{2} \mathrm{SO}_{4}$ was used.

Boiled Egg Albumin, Egg White, and Yolk-Aqueous solution of egg albumin was boiled in a water bath for 10 minutes, the coagulant was dehydrated with ethanol and shieved. The powder thus formed was used as boiled egg albumin. Similarly, boiled egg white could be obtained, while boiled egg yolk was prepared without dehydration. 
Proteinase — Purified bacterial proteinase, showing the proteolytic activity of $630,000 \mathrm{PUD} / \mathrm{g}$ units ${ }^{1}$ was employed. This enzyme has its optimum $\mathrm{pH}$ at 7.2-7.4, but in the present experiments, for preventing thiamine decomposition, all the trials were carried out at $\mathrm{pH} 6.8$.

Thiamine and Its Derivatives — Thiamine hydrochloride, nitrate, rhodanide, dicetylsulfate, dibenzoylthiamine (DBT), and dibenzoylthiamine hydrochloride were used.

\section{Determination}

Fluorescence of thiochrome produced by $\mathrm{BrCN}$ method was determined with fluorometer (1).

\section{RESULTS}

\section{Adsorption of Thiamine on Frozen Soy Bean Curd}

To vessels containing $50 \mathrm{ml}$ of various concentrations of DBT, one piece of thawed and pressed soy bean curd, having a sponge-like construction, was soaked, whereby the curd instantly sucked up the liquid. 10 minutes later, this soaked curd was placed between two pieces of board and pressed for hydration till the weight of the curd showed the same value as that before soaking. The amounts of the vitamin contained in the pressed juice were given in Table I. As can be seen from the Table, in the concentration

TABLE I

Changes of Recovery in Varying Concentrations of Dibenzoylthiamine

\begin{tabular}{cccc}
\hline $\begin{array}{c}\text { Concentration } \\
\text { of DBT }\end{array}$ & $\begin{array}{c}\text { Amount of DBT } \\
\text { in pressed juice }\end{array}$ & Recovery & $\begin{array}{l}\text { Weight of } \\
\text { sample }\end{array}$ \\
\hline$\mu g / m l$ & $\mu g / m l$ & per cent & $g$ \\
100 & 12.4 & 12.4 & 43 \\
70 & 14.2 & 20.0 & 42 \\
50 & 7.3 & 18.6 & 42 \\
30 & 5.5 & 18.5 & 40 \\
10 & 0.9 & 10.0 & 43 \\
\hline
\end{tabular}

range of $10-100 \mu \mathrm{g}$ of DBT per $\mathrm{ml}, 80-90$ per cent was lost, if the dilution of thiamine with the water contained in the curd was not taken into consideration.

It became further necessary to investigate, if this loss was due to decomposition of the thiamine during soaking or to conversion to thiamine disulfide or to adsorption on the curd.

Since thiamine disulfide can easily be reduced by cysteine to thiamine, this reduction was carried out with the pressed juice obtained in the above experiment, but the amount of thiamine in this juice did not increase. Then, the juice was added to the thiamine solution of various concentrations and the

\footnotetext{
11 PUD corresponds to the enzyme activity which can liberate $1 \mu \mathrm{g}$ of tyrosine $(5.52 \times$ $10^{-6} \mathrm{mEq}$ ) per minute in $1 \%$ casein medium.
} 
recovery of the vitamin was determined. As shown in Fig. 1, the recovery was found to be satisfactory.

Thus the disappearance of the vitamin is assumed to be caused by some kind of combination of the vitamin with the curd. Though the exact nature of the reaction remains to be investigated, it was considered to be a kind of adsorption.

In these experiments, the curd aged for about 10 days was used. During the aging, the sponge-like construction of the curd was developed, which seems to have a great

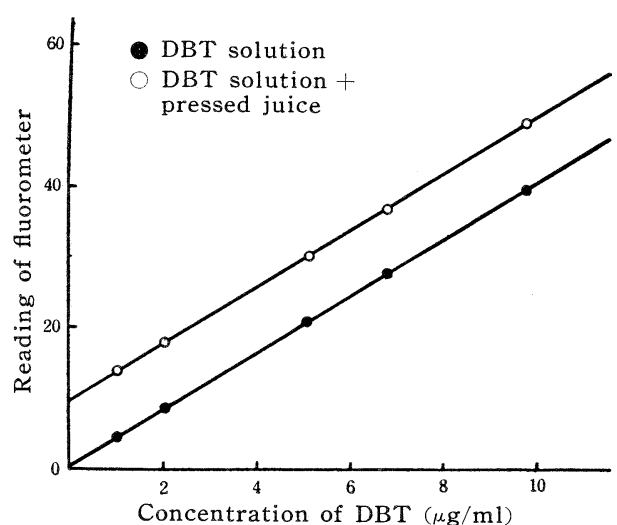

FIG. 1 Fluorescence Intensity vs. DBT Concentration effect on the adsorption. The relationship between the aging priod at $0^{\circ}$ and the adsorption of thiamine was further investigated. The changes of the amount of thiamine adsorbed on the curd, which had been stored for 3 to 15 days at $0^{\circ}$, was determined after freezing. As listed in Table II, the curd aged for 3 days showed the greatest adsorbability and it fell further with the period of aging.

TABLE II

Changes of Adsorbability with the Aging Period of Curd

Concentration of DBT, $100 \mu \mathrm{g} / \mathrm{ml}$. Soaking time, 10 minutes.

\begin{tabular}{ccc}
\hline Aging period & $\begin{array}{c}\text { Amount of DBT } \\
\text { in pressed juice }\end{array}$ & Adsorbability \\
\hline days & $\mu \mathrm{g} / m l$ & per cent \\
3 & 15.2 & 84.8 \\
6 & 16.7 & 83.3 \\
9 & 20.0 & 80.0 \\
12 & 20.3 & 79.7 \\
15 & 19.5 & 80.5 \\
\hline
\end{tabular}

TABLE III

Changes of Adsorbability with Soaking Time

Concentration of DBT solution, $100 \mu \mathrm{g} / \mathrm{ml}$

\begin{tabular}{cccccc}
\hline \multirow{2}{*}{ Soaking time } & \multicolumn{2}{c}{ Amount of DBT in pressed juice } & & \multicolumn{2}{c}{ Adsorption rate } \\
\cline { 2 - 3 } \cline { 5 - 6 } & $A$ & $B$ & & $A$ & $B$ \\
\hline $\min$ & $\mu g / m l$ & $\mu g / m l$ & & per cent & per cent \\
1 & 24.3 & 19.5 & & 75.7 & 80.5 \\
3 & 23.7 & 18.7 & & 76.3 & 81.3 \\
5 & 23.6 & 15.3 & & 76.4 & 84.7 \\
10 & 24.3 & 18.0 & & 75.7 & 82.2 \\
\end{tabular}

When the curd was soaked in the thiamine solution, the solution was 
sucked up almost instantly into the curd. The change in adsorbability with the soaking time was then examined. As seen from Table III, the adsorbability of the vitamin on the curd did not increase with the time of soaking.

The phenomenon was further tested with various kinds of thiamine derivatives. The following 6 derivatives were employed: thiamine $\left(B_{1}\right)$ hydrochloride, nitrate, rhodanide, dicetylsulfate, DBT, and DBT hydrochloride. As Table IV shows, DBT and DBT $\cdot \mathrm{HCl}$ were easily adsorbed on the curd, whereas $\mathrm{B}_{1} \cdot \mathrm{HCl}$ and $\mathrm{B}_{1}-\mathrm{SCN}$ were adsorbed less.

TABLE IV

Comparison of Adsorbability of Six Thiamine Derivatives

Concentration of each derivative expressed as free thaimine, $100 \mu \mathrm{g} / \mathrm{ml}$. Soaking time, 10 minutes.

\begin{tabular}{lcc}
\hline Thiamine derivative & $\begin{array}{c}\text { Amount of thiamine } \\
\text { in pressed juice }\end{array}$ & Adsorbability \\
\hline & $\mu g / m l$ & per cent \\
$\mathrm{B}_{1} \cdot \mathrm{HCl}$ & 41.6 & 58.4 \\
$\mathrm{~B}_{1} \cdot \mathrm{HNO} \mathrm{H}_{3}$ & 33.6 & 66.4 \\
$\mathrm{~B}_{1} \cdot \mathrm{SCN}$ & 51.9 & 48.1 \\
$\mathrm{~B}_{1}$ dicetylsulfate & 32.5 & 67.5 \\
$\mathrm{DBT}$ & 15.2 & 84.8 \\
$\mathrm{DBT} \cdot \mathrm{HCl}$ & 12.0 & 88.0 \\
\hline
\end{tabular}

\section{Determination of Thiamine Adsorbed on Protein}

In the preceding experiments, the mechanism of thiamine disappearance during the soaking process was supposed to be the adsorption of the vitamin on the curd based only on the observations that the addition of cysteine had no effect on the recovery of the vitamin of the pressed juice and a high recovery was obtained when the vitamin was added to the pressed juice. If the thiamine was adsorbed on the curd, the total amounts of thiamine in both the curd and the pressed juice must be equal to the sum of the vitamin in the soaking solution and that contained originally in the curd, while the sum of the vitamin determined was found not to exceed 50 per cent of the calculated value.

It is therefore assumed that the thiamine adsorbed tightly on the curd can not be determined by the conventional method. For determining the vitamin in this condition, it seems to be necessary to loosen the force of adsorption by some treatment on the curd prior to the determination. If the sum of the vitamin recovered from both the curd and the juice approach to 100 per cent by this pretreatment, the characteristics of the combination between the vitamin and the curd will become clear. For this purpose, the degradation of the curd by proteinase was undertaken.

The thiamine-adsorbed curd was pulverized in a glass mortar, and soaked in 0.1 per cent proteinase solution, 5 per cent Taka-diastase solution ( $\mathrm{pH}: 4.5)$, and water, respectively, overnight at room temperature. Thereafter, the same volume of $0.2 \mathrm{~N} \mathrm{HCl}$ solution was added to each solution to make the final concentration of the acid to $0.1 \mathrm{~N}$, and the vitamin was extracted from 
the acid solutions by boiling in a water bath for 30 minutes and assayed for thiamine. The effects of these pretreatments on the amount of the thiamine extracted were given in Table V. As the phosphatase occurring in soy beans had presumably degraded the cocarboxylase contained in soy beans during the process, the hydrolysis by Taka-diastase showed little effect, while by the action of proteinase on the curd, twice as much of the thiamine was extracted as compared with that without enzyme.

TABLE V

Comparison of the Amount of Thiamine Extracted with Various

Treatments

Sample, DBT-adsorbed soy bean curd

\begin{tabular}{lcc} 
& Amount of thiamine contained in one piece $(43 \mathrm{~g})$ of curd \\
\cline { 2 - 3 } Pretreated with & $A$ & $B$ \\
\hline & $\mu g$ & $\mu g$ \\
$0.1 \%$ Proteinase & 2500 & 1800 \\
$5 \%$ Taka-diastase & 1350 & 1150 \\
Water & 1330 & 920 \\
\hline
\end{tabular}

From the above experiment, it is known that a larger amount of thiamine can be obtained from the curd by proteinase pretreatment. Therefore the effect of varying concentrations of the proteinase was tested. As shown in Table VI, the amount of the vitamin extracted from the curd increased with the rise of proteinase concentration. It was observed above that the adsorption of thiamine was greatest in the case of $\mathrm{DBT} \cdot \mathrm{HCl}$ and smallest

TABLE VI

Changes in the Extracted Amount of Thiamine with the Concentration of Proteinase

\begin{tabular}{|c|c|c|c|c|c|}
\hline \multirow{2}{*}{$\begin{array}{l}\text { Proteinase } \\
\text { concentration }\end{array}$} & \multicolumn{4}{|c|}{ Amount of thiamine extracted from the sample } & \multirow{2}{*}{ Relative ratio ${ }^{a}$} \\
\hline & 1 & 2 & 3 & 4 & \\
\hline per cent & $\mu g / g$ & $\mu g / g$ & $\mu g / g$ & $\mu g / g$ & \\
\hline $\begin{array}{l}1.0 \\
0.5\end{array}$ & $\begin{array}{l}8.0 \\
7.5\end{array}$ & $\begin{array}{l}16.0 \\
15.0\end{array}$ & & & $\begin{array}{l}118.5 \\
113.0\end{array}$ \\
\hline 0.1 & 7.0 & 13.0 & 18.0 & 13.0 & 100.0 \\
\hline 0.05 & & & 14.5 & 11.0 & 82.5 \\
\hline 0.01 & & & 13.5 & 9.5 & 74.0 \\
\hline 0.005 & & & 12.5 & 8.5 & 64.2 \\
\hline 0.001 & & & 8.0 & 5.0 & 4.5 .3 \\
\hline
\end{tabular}

${ }^{a}$ The amount for 0.1 per cent proteinase solution was taken as 100 .

in the case of $\mathrm{B}_{1} \cdot \mathrm{SCN}$ of all the derivatives examined. The effect of 0.1 per cent proteinase treatment on the curd was, therefore, examined using the curd adsorbed with these derivatives. As can be seen from Table VII, $B_{1}$. $\mathrm{SCN}$, the least adsorbable, was found to give the least value of all the de- 
rivatives and $\mathrm{DBT} \cdot \mathrm{HCl}$, the most adsorbable, the greatest value.

TABLE VII

Comparison of the Recoveries of Added Thiamine Derivatives after Proteinase Treatment

\begin{tabular}{lccc}
\hline \multirow{2}{*}{ Derivative } & \multicolumn{2}{c}{ Thiamine extracted after treatment with } \\
\cline { 2 - 3 } & Water $(A)$ & Proteinase $(B)$ & $B / A$ \\
\hline & $\mu g$ & $\mu g$ & \\
$\mathrm{~B}_{1} \cdot \mathrm{HCl}$ & 51.0 & 96.0 & 1.87 \\
$\mathrm{~B}_{1} \cdot \mathrm{HNO}$ & 39.5 & 82.0 & 2.08 \\
$\mathrm{~B}_{1} \cdot \mathrm{SCN}$ & 67.0 & 78.5 & 1.17 \\
$\mathrm{~B}_{1}$-dicetylsulfate & 78.5 & 117.0 & 1.49 \\
$\mathrm{DBT}$ & 66.0 & 95.0 & 1.43 \\
$\mathrm{DBT} \cdot \mathrm{HCl}$ & 53.0 & 117.0 & 2.10 \\
\hline
\end{tabular}

Thus the proteinase pretreatment prior to $\mathrm{HCl}$ extraction gave, in some derivatives, twice as much thiamine values.

Six pieces of the tightly pressed curd were placed for 10 minutes in the vessel containing $50 \mathrm{ml}$ of one of six different thiamine derivatives, whose thiamine concentration was $100 \mu \mathrm{g} / \mathrm{ml}$ on a free vitamin basis. After press, the amount of the vitamin in the curd and of the pressed juice were determined after proteinase pretreatment. The recovery of the vitamin was calculated from the sum of both values against the sum of the content in the pieces $(320 \mu \mathrm{g})$, and in the soaking solution $(5000 \mu \mathrm{g})$, with the results given in Table VIII.

$T_{A B L E}$ VIII

Thiamine Recoveries of 6 Thiamine Derivatives

\begin{tabular}{lcccc}
\hline Derivative & $\begin{array}{c}\text { Amount of } \mathrm{B}_{\mathbf{1}} \\
\text { in pressed juice }\end{array}$ & $\begin{array}{c}\text { Amount of } \mathrm{B}_{\mathbf{1}} \\
\text { in curd }\end{array}$ & $\begin{array}{l}\text { Total amount } \\
\text { of } \mathrm{B}_{\mathbf{1}}\end{array}$ & Recovery \\
\hline & $\mu \boldsymbol{g}$ & $\mu \boldsymbol{g}$ & $\mu \boldsymbol{g}$ & $\%$ \\
$\mathrm{~B}_{1} \cdot \mathrm{HCl}$ & 1450 & 3840 & 5290 & 99.4 \\
$\mathrm{~B}_{1} \cdot \mathrm{HNO} \mathrm{H}_{3}$ & 1180 & 3280 & 4460 & 83.8 \\
$\mathrm{~B}_{1} \cdot \mathrm{SCN}$ & 1200 & 3340 & 4540 & 85.3 \\
$\mathrm{~B}_{1}$-dicetylsulfate & 1780 & 3870 & 5650 & 106.2 \\
DBT & 910 & 4480 & 5390 & 101.2 \\
DBT $\cdot \mathrm{HCl}$ & 720 & 4810 & 5530 & 104.0 \\
\hline
\end{tabular}

Thus by proteinase pretreatment, the amount of the thiamine in the curd was found to increase definitely, the recoveries approaching to 100 per cent. This method, therefore, is said to be recommendable for determining thiamine in foods of high protein content.

\section{Mechanism of Adsorption of Thiamine on Protein}

The thiamine disappeared after soaking the curd in thiamine solutions is assumed to have been adsorbed on the curd, since the vitamin disappeared was again recovered by hydrolyzing the curd by proteinase. The mechanism 
of the adsorption as well as the type of the reaction were therefore studied. Each of aqueous suspensions of glycinin, soy beans curd powder, and defatted curd powder was packed with suction into a cylindrical tube placed upon a sintered glass filter. After washing the column with a small amount of distilled water, $5 \mathrm{ml}$ each of thiamine solution of varying concentrations was passed through, the content of the vitamin in the effluents was determined. The results were given in Table IX. The results of similar experiments using egg albumin, denaturated egg albumin, boiled egg white, and boiled egg yolk were summarized in Table X.

TABLE IX

Adsorption of Thiamine on Various Proteins $(I)$

Amount of the protein packed in column, $1 \mathrm{~g}$. Volume of the effluent collected, $25 \mathrm{ml}$.

\begin{tabular}{|c|c|c|c|c|c|c|c|}
\hline \multirow{2}{*}{$\begin{array}{l}\text { Amount } \\
\text { of } B_{1} \\
\text { added }\end{array}$} & \multirow{2}{*}{$\begin{array}{l}\text { Amount of } \\
B_{1} \text { in effluent } \\
\text { calculated }\end{array}$} & \multicolumn{2}{|c|}{ Glycinin } & \multicolumn{2}{|c|}{$\begin{array}{l}\text { Soy bean curd } \\
\text { powder }\end{array}$} & \multicolumn{2}{|c|}{$\begin{array}{l}\text { Defatted curd } \\
\text { powder }\end{array}$} \\
\hline & & $\begin{array}{l}\mathrm{B}_{1} \text { in } \\
\text { effluent }\end{array}$ & Adsorbed & $\begin{array}{l}B_{1} \text { in } \\
\text { effluent }\end{array}$ & Adsorbed & $\begin{array}{l}B_{1} \text { in } \\
\text { effluent }\end{array}$ & Adsorbed \\
\hline$\mu g$ & $\mu g / m l$ & $\mu g / m l$ & per cent & $\mu g / m l$ & per cent & $\mu g / m l$ & per cent \\
\hline 0 & 0 & 0.08 & & 0.10 & & 0.10 & \\
\hline 5 & 0.2 & 0.04 & 80 & 0.01 & 95 & 0.01 & 95 \\
\hline 25 & 1.0 & 0.23 & 77 & 0.02 & 98 & 0.04 & 96 \\
\hline 50 & 2.0 & 0.68 & 66 & 0.08 & 96 & 0.10 & 95 \\
\hline 250 & 10.0 & 3.52 & 65 & 0.06 & 99 & 0.06 & 99 \\
\hline
\end{tabular}

TABLE X

Adsorption of Thiamine on Various Proteins (II)

Amount of the protein packed in column, $1 \mathrm{~g}$. Volume of the effluent collected, $25 \mathrm{ml}$.

The figures indicate percentage adsorption.

\begin{tabular}{rcccc}
\hline $\begin{array}{l}\text { Amount of } B_{1} \\
\text { added }\end{array}$ & Egg albumin & $\begin{array}{l}\text { Boiled denaturated } \\
\text { egg albumin }\end{array}$ & Boiled egg white & Boiled yolk \\
\hline$\mu g$ & & & & \\
0 & - & 70 & 60 & -5 \\
5 & -40 & 66 & 78 & -10 \\
25 & -34 & 58 & 80 & -11 \\
50 & -53 & 41 & 87 & -8 \\
250 & -37 & & \\
\hline
\end{tabular}

Thus it was found that soy bean curd powder, a sort of denaturated glycinin, could adsorb more thiamine than glycinin itself, and the removal of fat from this powder did not affect its adsorbability. The possibility that lipoprotein may be the active form of the curd protein is excluded by this experiment. Further, the denaturation of proteins was found to activate the reaction.

In the case of egg albumin, some fluorescent substances were contaminated in the effluent. However, both egg albumin and egg white after denaturation were found to adsorb the vitamin considerably. From the above findings, some relationship is assumed between the adsorption of the vitamin 
and denaturation of proteins. The negative result obtained with boiled egg yolk and defatted curd powder seems to suggest that lipoprotein has nothing to do with the reaction. Similar experiment using casein gave negative results, showing that the protein takes no part in the reaction.

The amount of the thiamine adsorbed on protein was found to increase by its denaturation, whereby the number of free sulfhydryl group is known to increase. For studying the relationship between denaturation and adsorption, the change in adsorbability by blocking the sulfhydryl group with some special reagents was examined as follows.

After washing the column containing $1 \mathrm{~g}$ of glycinin, soy bean curd powder, boild denaturated egg albumin, and boiled egg white, respectively, with distilled water, $5 \mathrm{ml}$ of $p$-chloromercuribenzoate (PCMB) solution of varying concentrations or water was passed slowly through the column, which was then washed with $5 \mathrm{ml}$ of water and $5 \mathrm{ml}$ of $5 \mu \mathrm{g} / \mathrm{ml}$ thiamine solution was passed through. The vitamin contents of these effluents were determined, with the results given in Table XI.

TABLE XI

Changes in Percentage Adsorption by p-Chloromercuribenzoate Treatment

\begin{tabular}{ccccc}
\hline \multirow{2}{*}{$\begin{array}{l}\text { Concentration } \\
\text { of PCMB }\end{array}$} & Glycinin & Soybeans curd & $\begin{array}{c}\text { Boiled egg } \\
\text { albumin }\end{array}$ & $\begin{array}{c}\text { Boiled egg } \\
\text { white }\end{array}$ \\
\cline { 2 - 4 } & & & & \\
\hline$M$ & 70 & 97 & 51 & 90 \\
0 & 86 & 100 & 97 & 92 \\
$1 / 1,000$ & 89 & 98 & 92 & 81 \\
$1 / 500$ & 73 & 100 & 96 & 98 \\
$1 / 100$ & & & & \\
\hline
\end{tabular}

Blocking the sulfhydryl group with PCMB seems to have no effect on thiamine adsorption ; moreover, it seems to promote the adsorption on some proteins, e.g., egg albumin. Therefore, the sulfhydryl group in protein seems to have no connection with the adsorption. In the case of egg albumin, it was the more difficult to pass a liquid through the column, the more denaturation

TABLE XII

Change in Percentage Adsorption by Treatment with Hydroxylamine

\begin{tabular}{ccccccc}
\hline & \multicolumn{5}{c}{ Percentage adsorption } \\
\cline { 2 - 6 } $\begin{array}{c}\text { Concentration } \\
\text { of } \mathrm{NH}_{2} \mathrm{OH}\end{array}$ & Glycinin & $\begin{array}{l}\text { Soy bean } \\
\text { curd }\end{array}$ & $\begin{array}{l}\text { Egg } \\
\text { albumin }\end{array}$ & $\begin{array}{l}\text { Boiled egg } \\
\text { albumin }\end{array}$ & $\begin{array}{l}\text { Boiled egg } \\
\text { white }\end{array}$ & Casein \\
\hline$M$ & 76 & 95 & -7 & 68 & 85 & -4 \\
0 & 80 & 91 & -7 & 71 & 89 & -1 \\
$1 / 1,000$ & 75 & 88 & -7 & $\overline{61}$ & 58 & -6 \\
$1 / 500$ & 68 & 82 & -14 & -14 & -10 \\
$1 / 100$ & 49 & 47 & -14 & -33 & 54 & -14 \\
$1 / 50$ & -8 & 5 & -27 & 33 & & -10 \\
$1 / 10$ & -8 & & & & & \\
\hline
\end{tabular}


proceeded, so the treatment was made by centrifugation, and it was found that the treament had no effect. Further, treatment with hydroxylamine was tried in some proteins. As seen from Table XII, the adsorption of thiamine on protein was greatly inhibited by hydroxylamine.

\section{DISCUSSION}

The above experiments clearly show that the disappearance of thiamine by soaking soy bean curd in the vitamin solution was not due to the decomposition but to the combination of the vitamin with curd protein, possibly by adsorption.

Egg albumin failed to adsorb the vitamin, in contrast to the denaturated one. Glycinin denaturated with urea was also found to adsorb more thiamine than the native one. Therefore, some groups involving this reaction is assumed to become more active, possibly occurring between liquid-solid phase rather than liquid-liquid phase. Inhibition of the reaction by hydroxylamine seems to suggest the participation of a carbonyl group as an active center of the adsorption.

\section{SUMMARY}

1. When frozen soy bean curd was soaked in a thiamine solution for a short time, the vitamin disappears from the juice obtained by pressing the curd.

2. This disappearance of thiamine was found neither to be due to oxidation to thiamine disulfide nor to its decomposition by some factors contained in the curd, but to its adsorption on the curd.

3. This adsorption occurs rapidly and tightly.

4. The adsorption increased by denaturation of the protein, whereby a carbonyl group of the protein seems to have some connection.

5. The thiamine adsorbed tightly on the protein could be extracted after hydrolyzing the protein with proteinase.

\section{REFERENCE}

1. Fujiwara, M., and Matsui, K., Anal. Chem. 25, 810 (1953). 